\title{
FLOUTING MAXIMS AND THE IMPLICATIONS TO MAJOR CHARACTERS IN PAULO COELHO'S THE WINNER STANDS ALONE
}

\author{
Afif Ikhwanul Muslimin \\ UIN Maulana Malik Ibrahim Malang \\ afif.ikhwanul@gmail.com
}

\begin{abstract}
Communication needs the effectiveness of delivering information from the speaker to the hearer. Due to this reason, Griece offers to use the theory of cooperative principle to avoid misunderstanding between the speaker and hearer which consist of maxims. Aside from cooperative principle, Svoboda promotes politeness theory (maxims) that also has an enormous influence in a successful conversation. However, the speakers and the hearers as the participants of communication sometimes violate the maxims. The violation of maxims can cause flouting maxims. This paper is focused on analyzing flouting maxims on Igor as the main character in Paulo Coelho's The Winner Stands Alone novel context and their implications of those communication breakdowns to the other major characters in the novel. Referring to the descriptive analysis of the novel, it was revealed that Igor had violated maxims in the cooperative principle was denoted by various indicators, namely redundancy, less informative, out of topic, obscurity, ambiguity, and disorderliness. Moreover, sometimes Igor did not take account at others' feeling by violating six maxims in the politeness principle. Hence, Igor as the main character in the novel found himself in troubles in his relationship with girlfriends, wife, and colleagues. Finally, the findings can be used to raise the novel readers' awareness on the importance of cooperative principle and politeness principle to be applied in real life communication in order to provide knowledge for the readers on how to apply language by making them aware of possible violation.
\end{abstract}

Keywords: floating maxim, implications, major characters

People always need others because they cannot do many things by themselves. They need motivation, support, attention from others in order fulfill their needs. Hence, interacting with others, communication via language becomes a necessity.

Good communication requires people to properly understand and produce a particular linguistic forms at the communication speech events they are engaged. For that reason, people are careful at their language products in the sense that the way they speak and what they talk about may affect other's perception. In this case, it is important to consider the context of the communication. Hymes (2003:60-61) states that there are eight elements that determining the speech context. These elements are commonly abbreviated as SPEAKING. SPEAKING consists of setting and scene related with the place and the time of the speech being spoken, participant of the speech act that consist of the speaker and the listener, ends or in other word the purpose being achieved, act sequence related to the form and the content of the language, keys related to the intonation and the gesture while speaking, instrumentalities related to the media being used to deliver the message, norm of interaction related to linguistic rules being 
used by the participants, and genres related to the discourse type (official or unofficial).

In fact, in many occasions, communication does not always run smoothly. The failure of the communication happens because people are not aware of the aformentioned communication context. Hence, it causes misunderstanding among the speakers. In the end, this communication failure possibly harms interpersonal relationship.

The novel The Winner Stands Alone by Paulo Coelho is a very interesting novel to be observed pragmatically. This novel provides many reflections about communication breakdowns. We can see this in what Igor, the main character in this novel, does when communicating with other characters. In pragmatic, communication breakdown occurs especially because of the speaker intentional violation toward communication maxims of cooperative principles. As in the following example when Igor, the main character, is communicating with another character, Olivia.

\begin{tabular}{|c|c|}
\hline or & $\begin{array}{l}\text { "But I was too proud. I thought it } \\
\text { was just temporary move and that } \\
\text { she would soon realize her mistake. } \\
\text { I'm sure she regrets leaving me and, } \\
\text { as I said, wants to come back. } \\
\text { But that for to happen I need } \\
\text { to destroy a few worlds" }\end{array}$ \\
\hline Olivia & $\begin{array}{l}\text { : (Gets up) "Well, I need to do } \\
\text { some work" }\end{array}$ \\
\hline & $\begin{array}{l}\text { "But I paid you to listen to me. } \\
\text { I paid enough to cover your whole } \\
\text { working day" }\end{array}$ \\
\hline livia & $\begin{array}{l}\text { : (return back the money) } \\
: \text { (show the pistols) "Sit down!" } \\
\text { (Coelho, 2009:18) }\end{array}$ \\
\hline
\end{tabular}

From the conversation above we can see Olivia has violated the Maxim of Tact, where she should not offend Igor's feeling by her speech. Through her action, Olivia has violated the politeness theory by only considering her own interest so that Igor felt offended. At the end of the conversation, what Igor did shows that he felt offended with Olivia's action. Things like this are commonly categorized as the form of misunderstanding.

The Winner Stand Alone itself is the thirteenth novel by Paulo Coelho and was published in 2008. The story of the novel The Winner Stands Alone is just as enticing as the previous novels by Paulo Coelho such as The Alchemist and The Devil and Miss Prym. Just like in the previous novels, this novel provides a story of human life examined from psychological point of view. The only different is that in this novel, Paulo Coelho provides a story with a background of an extravagant life of celebrities and top society. In this novel, we can learn reflection of interpersonal communication breakdowns between Igor, the main character, and the other major characters.

This research is expected to have theoretical significance, namely to verify the theories about speech act, cooperative principles, and politeness. In addition, the practical purpose is to enrich the repertoire of knowledge in terms of linguistic and literature relevance. Besides that, the result of this research will help the reader to perceive further about the novel The Winner Stands Alone by Paulo Coelho.

Some researchers studied subjects related with interpersonal communication and its breakdowns. The writer concludes that from most of the results, the researchers could not find any connection between interpersonal communication with a person's character development and also with the factors that beyond human control.

As described on a thesis entitled Gangguan Komunikasi Interpersonal Melalui SMS Antar Pelaku Komunikasi, "interpersonal communication disturbance theory by DeVito with face to face communication process can also be applied on other media like SMS. We also find two other disturbances, identity and delay breakdowns." (Stefanie, 2009:vi).

Almost similar with what's stated on Hambatan Komunikasi Interpersonal Remaja dengan Orang Tua dalam Kasus Kehamilan diluar Nikah, that "interpersonal communication between teenagers 
and parents in pre-marriage pregnancy tend to be hung up because of the emergence of the feeling of the disturbed self concept area which is highly connected with dignity" (Viana, 2009:iv).

From the explanation above we can conclude that what has been found so far is the connection between self-concept and interpersonal communication. We can summarize that if someone's self-concept being disturbed then his/her interpersonal communication would be having breakdowns as well.

Therefore the writer tries to apply the stated theories and results to further investigate the communication breakdowns that might occur on Igor, the main character on the novel The Winner Stands Alone.

\section{METHOD}

The subject of this study is the novel by Paulo Coelho entitled The Winner Stands Alone. The writer uses a novel published by Harper Collins in 2009 with 375 pages. The novel The Winner Stands Alone is available in various languages.

The research is focusing on Igor, the main character in the novel The Winner Stands Alone, while the analysis would be focusing on the communication process conducted by Igor and the aftermath of the communication. Both verbal and nonverbal communication process is included as the subject of the research.

The research method used in this research is the method of qualitative description. The writer analyzed the occurring phenomena when the communication process from the main character is being conducted and the effect of that communication. The data would be listed based on what happened and what is being said from the main character in the novel. The writer uses pragmatic review through speech acts theory, principle of cooperation, and theory of politeness in order to obtain data. The obtained data is in form of words and sentences used and also the behavior shown by the main character.
In gathering data, the writer uses several steps as follows. After the writer gets the novel, she read the novel for several times in order to fully understand the situation and the condition of the main character. As the second step, the writer begins to re-read the novel and enlist the communication process of the main character, and also the events that occurred as the aftermath of the communication. The notes made by the writer consist of when the communication occurs, the situation when the communication occurs, what message being delivered, and the events before and after the communication occurs.

After the writer gathers all the data, she conducts several steps to analyze the data further. As the first step, the writer analyzes the dialogs conducted by the main character based on speech acts theory, principle of cooperation, and theory of politeness. Next, she uses the theory of communication to determine whether the communication process is going smoothly or having a breakdown and what are the implications based on the theory of implicature. The writer would use the result of the analysis to interpret the result of the research and answer the existed problem statement. As for the last step, the writer would give conclusions based on the process and the result of the analysis.

\section{FINDINGS AND DISCUSSION}

\section{The Description of the Maxim Analysis of All Characters Conversation}

\section{Conversation: Igor and Ewa (Page 86-98)}

Igor : "I have destroyed a world for you, Katyusha."

Ewa : "Yes, I'm satisfied, but the problem is you're not, and neverwill be. You're insecure, afraid of losing everything you've achieved; you don't know how to quit once you're ahead. You'll end up destroying yourself. You're killing our marriage and my love." 


\section{The Analysis:}

This is included as locutionary which means Ewa states clearly her intention and feeling toward Igor. According to the cooperative principle, Ewa violated Maxim of relevance in which Ewa's statement does not match with Igor statement in previous. Instead of that, according to the politeness principle, Ewa violates the maxim of tact which Ewa explicitly states her feeling toward Igor which may be so painful for Igor.

\section{Conversation: Igor and People (Page 157)}

Igor : "If some madman stabs to death a few innocent people, the whole world is shocked, but who cares about the intellectual violence being perpetrated in Cannes? Our festival is being killed in the name of a dictatorship. It's not a question of choosing the best film, but of committing crimes against humanity, forcing people to buy products they don't want, putting fashion above art, choosing to go to a lunch or a supper rather than watch a film. That's disgraceful. I'm here to - "

Igor : "I'm here to denounce the enslavement of man's desires, for we have stopped using our intelligence to make choices and instead allow ourselves to be manipulated by propaganda and lies! People get all steamed up about these stabbings in Tokyo, but they don't give a damn about the death by a thousand cuts suffered by a whole generation of filmmakers."

\section{The Analysis:}

Igor shows locutionary meaning since he wants to convince the people around to believe on what he says. According to the cooperative principle, he shows maxim of quantity which he shows his availability to explain more on what he has stated. According to the politeness principle, he has violated maxim of agreement in which he states strongly his belief to the people around him.
Conversation: Igor and Maureen (Page 162-169)

Maureen

: "May I sit here? All the other tables are occupied."

Igor

: "You already are

sitting here."

\section{The Analysis:}

Igor's answer shows locutionary meaning to Maureen which he states explicitly on his idea. According to the cooperative principle, he breaks the maxim of quantity and manner. The way he speaks is to limited in answer and his manner to let the girl sits create biased meaning. According to the politeness principle, he breaks maxim of tact and maxim of modesty by stating harshly his permission to the girl to sit and he shows his arrogance.

Conversation: Igor and Maureen (Page 169172)

Maureen : "It's lovely here! Do you know why God decided to rest on the seventh day?"

Maureen : "Because on the seventh day, before he'd finished work and left the world in a perfect state for human beings, a group of producers from Hollywood came over to him and said: 'Don't you worry about therest! We'll take care of providing the Technicolor sunset, the special storm effects, the perfect lighting, and the right sound equipment so that whenever Man hears the waves, he'll think it's the real sea!' "She laughs to herself. The man beside her is looking more serious now.

\section{The Analysis:}

Maureen's statement shows locutionary meaning. According to the cooperative principle, Maureen shows maxim of manner by stating everything that he wants to say to Igor. According to the politeness principle, Maureen shows maxim of generosity by explaining clearly what she means.

\section{Conversation: Igor and Ewa (Page 203-204)}

Ewa : "I left it all behind," Ewa said on one of the tapes. "And I don't regret it one 
bit. I would have done the same even if Hamid-against my wishes - hadn't bought that beautiful estate in Spain and put it in my name. I would have made the same decision if Igor, my ex-husband, had offered me half his fortune. I would have taken the same decision because I know that I need to live without fear. If one of the most desirable men in the world wants to be by my side, then I'm obviously a better person than I thought."

Ewa : "My husband has lost his reason. Whether it stems from his war experiences or stress from overwork, I've no idea, but he thinks he knows what God intends. Before I left, I sought advice from a psychiatrist in order to try and understand him better, to see if it was possible to save our relationship. I didn't go into details so as not to compromise him and I won't do so with you now, but I think he would be capable of doing terrible things if he believed he was doing good."The psychiatrist explained to me that many generous, compassionate people can, from one moment to the next, change completely. Studies have been done of this phenomenon and they call that sudden change 'the Lucifer effect' after Lucifer, God's best-loved angel, who ended up trying to rival God himself."

\section{The Analysis:}

Ewa's statement shows her locutioary meaning related to her family real condition especially about Igor. According to the cooperative principle, Ewa tends to apply maxim of manner by being honest to herself. According to the politeness principle, she uses maxim of generosity by telling everything she feels.

\section{Conversation: Igor and Ewa (Page 219)}

Phone says : "You have a message."

Ewa : "What a ridiculous bit

$$
\text { of animation," thinks Ewa. }
$$

\section{The Analysis:}

Ewa shows illocutionary meaning toward the message she gets which actually from Igor. According to the cooperative principle, Ewa breaks maxim of relevance in which her response to the message is not match. Ewa in the politeness principle breaks maxim of tact by not replying the message which her response will hurt Igor.

\section{Conversation: Igor and Gloria (Page 296-} 297)

Artist : "Oh, do you smoke cigars?" Igor : "Yes, but only after supper."

\section{The Analysis:}

Igor's answer employs locutionary meaning by stating clearly his meaning in his utterance. According to the cooperative principle, he employs maxim of relevance by giving relevance answer to Gloria. According to the politeness principle, he employs maxim of tact by not hurting Gloria with his answer.

\section{Conversation: Igor and Gloria (Page 315- 316)}

Igor : "Yes, of course, I'll be glad to take you home."

Gloria : "Don't you think we should go in?"

Igor : "Yes, but I know how these things work. It's best to wait until everyone else is seated. Several of the tables will have places reserved at them for certain people, and we don't want to find ourselves in the embarrassing position of sitting down where we shouldn't."

\section{The Analysis:}

Igor shows his locutionary meaning in his statement. According to the cooperative principle, he shows maxim of manner by stating clearly what he wants. According to the politeness principle, he employs maxim of tact by giving polite refusal on Gloria's request and avoid to hurt her. 
Conversation: Igor, Gabriela, Hamid, and Ewa (Page 316-321)

Hamid : "Igor!" Hamid says.

Ewa : "What are you doing?"

Igor : "One day, I'll be back, and then you'll see what I'm capable of."

\section{The Analysis:}

Igor's answer to Ewa and Hamid shows his illocutionary meaning in which he implicitly wants to remind Ewa that he can do what he wants. According to the cooperative principle, Igor breaks maxim of relevance because his response is not match with Ewa's questions. According to the politeness principle, he breaks maxim of tact by creating ambiguous sentence as replay of Ewa's question. He also breaks maxim of modesty since he shows his arrogance toward the situation he meets Ewa and Hamid.

Conversation: Igor and Hamid, and Ewa (Page 321-334)

Igor : "I hope you got m y messages,"
says Igor.
Ewa :I received three. Perhaps the telephone
network here is worse than the one
you developed."
Igor : "I'm not talking about telephones."
Ewa : Then I don't know what you are talking
about," she says, but what, she wants
to say is: "I know you're not."

\section{The Analysis:}

Ewa's answer shows his illocutionary meaning to direct Igor to believe her that she does not do mistake related to Igor's message. According to the cooperative principle, she breaks maxim of quality by laying to Igor about the message. According to the politeness principle, she breaks maxim of tact that her answer hurts Igor feeling.

Conversation: Igor and Gabriela (Page 336337)
Gabriela : "I've been looking for you! Where are your friends?"
Igor : "Where's yours?"

: "He's gone. He said there was some problem with the actor and the director, that's all, and then he left. The only other thing he said was that tonight's party on the yacht has been canceled."

\section{The Analysis:}

Igor's statement shows declarative illocutionary since he wants to declare everything has been fine and he hides the reality. According to the cooperative principle, Igor violates maxim of quality since he lies about the party in yacht and the reality that happen to Hamid and Ewa. According to the politeness principle, Igor employs maxim of tact in which does not want to hurt Gabriela about his murder to Hamid and Ewa.

\section{The Implication of Main Character's Violation to Maxims \\ The Implication of Violation to the Principles of Cooperatives}

\section{Maxim of Quantity}

Igor as main character has done some violation on the use of maxim of quantity. As the example when Igor must reply Ewa's questions about what Igor did to the beggar, he did not give satisfactory answer. He said "I saved him..". It creates Ewa's disappointment to Igor. Since Ewa and Igor have already had bad family relationship, Ewa's bad impression to Igor gets more. Another Igor's conversation with other character that is Maureen, Igor shows his "cool" characteristics trough his very short answer than what Maureen may hope. For example, when Maureen asked for sit, Igor seems neglect and says very short answer "You already are sitting here." It makes Maureen feels that she may be wrong to ask for sit beside Igor. Fortunately, Maureen is not too sensitive girl that will be irritated by Igor's statement. The other example when Maureen explained a lot about the artist in Cannes, Igor just gives another short reply "Oh, I know what that's like." Igor seems to be ignorance to Maureen's statement. Again, Maureen thinks that this man (Igor) is good man. 


\section{Maxim of Quality}

In many conversations that Igor made with Ewa, Igor often creates dishonest statement. The first example when he talks to Ewa about the Beggar that both of them met in the café, Igor states that he saved him. Although Ewa has tried to confirm again on what he did to the beggar, Igor did not give a satisfactory answer to Ewa. Moreover, he tells his goodness to Ewa which then fortunately able to make Ewa believes on him. Although, in the next subchapter of this novel, Ewa realize that Igor has lied and said that he killed the beggar. The Igor's dishonesty in his statement toward Ewa creates more Ewa's hatred to him. The same action was done by Igor when Gabriela asked about where Hamid and Ewa were. But, since Gabriela never had bad experience with Igor, she thought that Igor's statement is truly happen.

\section{Maxim of Relevance}

Igor usually creates irrelevant answer toward Ewa's statement that direct to their separation. For example, when Ewa starts to touch their relationship situation by stating "My love, I'd like to ask you something else..." Igor pretends to not understand and try to avoid it. One of his avoidance to Ewa's statement is "Drink less next time." pointing Ewa as if she is under alcohol. Maybe Igor feels afraid that finally Ewa really wants to repel Igor from her life. Unfortunately, Igor still believes that Ewa did not understand on Igor's hard work. After some irrelevance answer, Ewa felt that Igor may not understand about the situation between them. Ewa become surer that Igor is not good for her. Another irrelevance conversation done by Igor is when he talks to Maureen, he made silly response "A good question," while Maureen is actually want to know who Igor is. In this case, Igor did not create influential effect to Maureen since Maureen is still new and believe that Igor is good man.

\section{Maxim of Manner}

Igor's violation to maxim of manner is mostly done when he is talking with Ewa. It is because the main conflict in this novel is between Igor and Ewa. In a position Igor believes that he does not do any mistakes realted to his business and attention to Ewa. He thinks that he does his best for Ewa. Although Ewa thinks that actually Igor has married with his job rather than with her. Until Igor realizes that Ewa really wants to separate herself from Igor, Igor starts to be crazy. He thinks that by killing people (as the worst sin) will show his deep and sincere love to Ewa. Igor get scared and scared until Ewa divorced him and married with Hamid. Since then, Igor always tries to show his power anytime he answered Ewa's questions such as "Even if you slept with every man on Earth, my love would still survive." It shows that he violate maxim of manner when he creates biased answer. It seems like he gives chance for Ewa to try to get married with other man first and Igor will still wait and love Ewa. But, actually Igor never gives that chance to Ewa because of Igor's power and arrogance. Igor also shows his other biased answer when Ewa asked about the existence of the beggar that they met in café. Since Igor did not want to be looked as bad man, he said his service when he was army to convince Ewa. At first it works and Igor gets Ewa's attention because of his biased answer.

\section{The Implication of Violation to the Principle of Politeness}

Igor is as the main character and as the victim of the divorce done many violation of maxim of tact to Ewa. According to the theory of maxim of tact, Igor tends to neglect what Ewa thinks about him. He always tries to turn Ewa's talk when Ewa talks about divorce. Moreover, Igor always says harshly and reject strongly about Ewa's objection on his love such as "Don't say that, don't say I'm killing our love. I promise that soon we'll leave all this behind us, just be patient. Perhaps you should start some project of your own because your life at the moment really must be pretty hellish." That shows that Igor has hurt Ewa's feeling. Another example that shows Igor's bad response to Ewa is "I didn't need to. You know that I care about other people.". Here, Ewa gets 
hurt because she thinks that Igor has made her as real life partner and will share everything that Igor does. But, finally she realized that Igor does not need to tell something to Ewa as his wife.

\section{Maxim of Generosity}

Igor just shows his violation to the maxim of generosity to Maureen, the girl that suddenly comes and wants to create conversation with him in café. It is normal since Igor does not know a lot about the girl yet. In addition, he comes to Cannes is not for other girl, but it is for Ewa as when Igor suddenly remember about Ewa "Perhaps Ewa is receiving news rather than information," when Maureen talks about gold-plated computer.

\section{Maxim of Approbation}

Since Igor as the main character in this novel has very wonderful job as the owner of the biggest telecommunication company in Russia and he comes to Cannes and auction as the guest, Igor has very prestigious position and makes him possibly to be arrogance. That's why it is really hard to find him to praise other character. He tends to praise his superiority. Once he insult other, the poor, is when he says "I saved him from a filthy,...". It creates a bad image in other character about Igor in the novel.

\section{Maxim of Modesty}

Igor's position as the high class man makes him proud of himself. It influences his response to some character's talk in this novel. For example, when Igor answers Ewa's questions, he always shows his arrogance such as "No one, absolutely no one, can threaten our privacy...". He believes that he is the richest person and no one is brave enough to disturb him. Another occasion when Igor has met Ewa and Hamid, Igor who is actually feeling guilty of his action to love his job more than his wife shows that he is the right one. He said "And yet, despite all the injustices and humiliations, I would have done anything to have you back - until today. Until I sent you those messages, and you pretended not to have received them. In other words, even the sacrifice of those other people didn't move you; you just couldn't get enough of power and luxury.". Igor's violation to maxim of modesty makes his position in Ewa become worse. He would never get Ewa back since Igor's superiority and belief to be true made Ewa surer that Igor was really crazy.

\section{Maxim of Agreement}

Igor always disagrees to Ewa's opinion about himself and Ewa's objection to Igor's busy in his business. As an example is "God thought of everything," "We are together because...". In this statement Igor repels Ewa's opinion that they cannot be together forever with that situation. Another example is "I'd make you come back, and I'm good at getting what I want,...". This example shows that Igor in his heart strongly opposes Ewa's statement to move to other heart but he said it in more gentleman way. For women, Igor's gentleman way shows Igor's craziness since what Ewa wants was Igor change into more attentive husband to her. So, the Igor violation to maxim of agreement makes his position insecure in Ewa's mind and perception.

\section{Maxim of Sympathy}

In this novel, Igor who has psychology problem with his wife, then divorce, seems never paying attention to his wife feeling. His wife often teases Igor related to her inconvenience to Igor such as: Igor has married with his job and neglects his wife, Igor has given her luxurious things but he never gives her flower, Igor never believes Ewa as place to share problem, and Igor always be arrogant. The Igor's neglecting to Ewa's feeling has ruined Igor's marriage with Ewa. It always makes their conversation and moment feels inconvenient.

\section{CONCLUSION}

Based on the discussion and analysis above, we can conclude that Igor as the main character in the novel has violated maxims in both principle of cooperative and politeness. Further, he also employs theory of implicature in both 
conventional and conversational implicature. Then all his practices on maxims violations

\section{REFERENCES}

Bernardo, K. (2012). Characterization on Literature. Retrieved from http:/ / learn.lexiconic. net/characters.html on 10 April 2012.

Cita, A. (2006). Analisis Prinsip Kesopanan pada Novel Madame Bovary Karya Gustave Flaubert (Kajian Pragmatik). Retrieved from http:/ / elib.unikom.ac.id/files/ disk1/66/jbptunikompp-gdl-s1-2006angguncita-3295-cover.pdf on 4Februari 2012.

Coelho, P. (2009). The Winner Stands Alone. NY: Harper Collins.

Cuddon, J.A. (1998). The Pinguin Dictionary of Literary Terms and Literary Theory. England: Clays Ltd.

Grice, H.P (2004) Logic and Conversation. London: University Collage London.

Hymes, D. (2003). Models of the Interaction of Language and Social Life. Retrieved from www.stanford.edu $\% 2 \mathrm{~F} \sim$ tylers \%2Fnotes\%2Femotion\%2FHymes_1 972_reading_notes_Schnoebelen.pdf on 13 April 2012.

Jumanto, D.R. (2011). Pragmatik Dunia Linguistik tak Selebar Daun Kelor. Semarang: produced many implications to other main character in Paulo Coleho's The Winner Stands Alone.

WorldPro Publishing.

Moeschler, J. (2003). Conventional and Conversational Implicatures. Retrieved from www. unige.ch/.../implicature-moeschlerdef.pdf on 17 April 2012.

Stefanie, R. (2009). Gangguan Komunikasi Interpersonal Melalui SMS Antar Pelaku Komunikasi. Retrieved from http:// dewey.petra.ac.id/jiunkpe_dg_11515. html on 8 January 2012.

Suryani, R. (2009). Prinsip Kerjasama Terkait dengan Tindak Ilokusi Pada Sandiwara Ketoprak dengan Lakon Suminten Edan. Retrieved from http:/ / lontar.ui.ac.id/ file?file $=$ digital $/ 123486-$ RB02R40pPrinsip\%20kerja-Pendahuluan.pdf on 24 January 2012.

Svoboda, A. (2004). Lectures on English Syntax. Ostrava: Ostravska Univerzita V Ostrave.

Viana, W. (2009). Hambatan Komunikasi Interpersonal Remaja dengan Orang Tua dalam Kasus Kehamilan Diluar Nikah. Retrieved from http:/ / dewey.petra.ac.id/jiunkpe_ dg_11652.html on 8 January 2012. 
